\title{
Benzothiadiazole Activates Resistance in Sunflower (Helianthus annuus) to the Root-Parasitic Weed Orobanche cumana
}

\author{
J. Sauerborn, H. Buschmann, K. Ghiasvand Ghiasi, and K.-H. Kogel
}

First, second, and third authors: University of Hohenheim (380), Department for Agroecology of the Tropics and Subtropics, D-70593 Stuttgart, Germany; and fourth author: University of Giessen, Institute of Phytopathology and Applied Zoology, D-35392 Giessen, Germany.

Accepted for publication 16 August 2001.

\begin{abstract}
Sauerborn, J., Buschmann, H., Ghiasvand Ghiasi, K., and Kogel, K.-H. 2002. Benzothiadiazole activates resistance in sunflower (Helianthus annuus) to the root-parasitic weed Orobanche cumana. Phytopathology 92:59-64.

The study was conducted to evaluate the potential of induced resistance to infestation of sunflower (Helianthus annuus L.) by the parasitic weed Orobanche cumana Wallr. Treatment of sunflower seeds with $40 \mathrm{ppm}$ of benzo(1,2,3)thiadiazole-7-carbothioic acid S-methyl ester (BTH) for $36 \mathrm{~h}$ completely prevented infection in root chambers. In pot studies using $2.86 \times 10^{-4} \mathrm{~g}$ of Orobanche seeds per gram of soil as inoculum, the total number of $O$. cumana shoots was reduced by 84 and $95 \%$ in the $60-\mathrm{ppm}$ BTH treatment in the first and second trial, respectively. Evaluation of
\end{abstract}

ABSTRACT

Certain members of the genus Orobanche, family Orobanchaceae, threaten agricultural production in many parts of the world. The most damaging Orobanche spp. spread in the Mediterranean region and western Asia, parasitizing important crops (27). O. aegyptiaca Pers. infests mainly legumes and Solanaceae genera such as egg plant, potato, tobacco, tomato, and others. $O$. crenata Forssk. and $O$. minor $\mathrm{Sm}$. parasitize preferentially grain and fodder legumes. Although Orobanche spp. are distributed worldwide, crop losses are only significant in southern and eastern Europe, North Africa, and western Asia. Orobanche spp. which limit crop production are presently reported from 58 countries. In the Mediterranean area and western Asia, $\approx 16$ million ha of crop land are threatened by Orobanche spp.; this is $\approx 1.2 \%$ of the world's arable land.

Sunflower plants are frequently infested by O. cumana. As a holoparasite, lacking chlorophyll, this plant is completely dependent on its host for its supply of water, minerals, and assimilates. The withdrawal of water, minerals, and organic compounds can lead to complete crop failure. In the former Yugoslavia, sunflower cultivation was reduced by $37 \%$ following an $O$. cumana infestation (25). Severe Orobanche infestation lowers not only seed yield but also the seed's oil content (32).

$O$. cumana is an important constraint of sunflower production in the Mediterranean basin and eastern Europe, as well as in China (26), where half of the world's sunflower seeds are produced (8). In Andalusia, Spain, the oil sunflower cropping area was assessed to be infested with $O$. cumana at $58 \%$ (10). The parasite has been introduced to eastern Asia (23) and most likely will spread further.

Corresponding author: J. Sauerborn; E-mail address: sauerbn@uni-hohenheim.de

Publication no. P-2001-1101-01R

This article is in the public domain and not copyrightable. It may be freely reprinted with customary crediting of the source. The American Phytopathological Society, 2002. the disease incidences revealed that attachment of $O$. cumana at the sunflower root and the stage of early penetration was reduced in the BTHtreated plants. Chemical analysis of root extracts revealed synthesis of the phytoalexin scopoletin and of hydrogen peroxide in the BTH-treated sunflower roots, but no increase in lignification. Western blot analysis demonstrated accumulation of the pathogenesis-related protein chitinase in roots and stems of induced resistant plants. These results show that the phenomenon of induced resistance is not restricted to viral, bacterial, and fungal disease and demonstrate the great potential of this protection strategy as an effective component of future plant production systems.

Additional keywords: broomrape, chitinase, phenylpropanoids, sunflower, systemic acquired resistance.
At present, no commercially available chemical herbicide can combat $O$. cumana with sufficient margin of selectivity and efficiency. Breeding programs have revealed resistant sunflower lines, but resistance is overcome once a new physiological race of $O$. cumana occurs (7). Microbial control of $O$. cumana using Fusarium oxysporum Schlechtend. f. sp. orthoceras (Appel \& Wollenweb.) Bilay is an approach aimed at the development of a commercial product $(33,34)$.

Alternative or supplementary methods for strengthening plant health or inducing the plant's defense system might be applicable for control of $O$. cumana infections. Induced resistance (IR) by means of synthetic inducers, in some crop systems, is a suitable strategy to utilize the plant's natural defense responses to control pathogens. IR, brought about by treating plants with the chemical benzo(1,2,3)thiadiazole-7-carbothioic acid S-methyl ester (BTH), has been demonstrated in dicotyledonous and monocotyledonous plants. The resistance-inducing activity of BTH probably relies on the activation of a natural defense pathway called systemic acquired resistance (SAR), as reviewed by Sticher et al. (31) and Lucas (24). However, the use and efficiency of chemical resistance inducers is still under discussion (16).

Therefore, the present study was undertaken to evaluate the potential of chemically induced resistance in the pathosystem of sunflower and $O$. cumana. Although there were no earlier reports on induced resistance to parasitic weeds, a careful inspection of histopathological data obtained in various interactions reveals that necrotization and browning at penetration sites is predominantly associated with resistant interaction phenotypes (45). This suggests involvement of phenylpropanoids, peroxidases (1), and reactive oxygen intermediates. Moreover, molecular studies on the interaction of Orobanche spp. with various host plants demonstrate accumulation of pathogenesis-related (PR) proteins, including a PR1 homologue (19) and 3-hydroxy-3-methylglutaryl CoA reductase (HMGR) (43). Conspicuously, enhanced activities of peroxidases, together with a wide range of other PR proteins, is 
a characteristic feature of the defense reaction underlying the SAR mechanism in plants to viral, bacterial, and fungal infection $(37,42)$.

In the present work, we tested BTH, the active ingredient of Bion, for the ability to enhance resistance in sunflower roots to infection with $O$. cumana. We show that this resistance-inducing chemical is effective for controlling $O$. cumana by preventing the establishment of an infection at an early interaction stage. The data again demonstrate the great potential of induced resistance as an effective component of future plant protection strategies.

\section{MATERIALS AND METHODS}

Origin of plant material. Seed of the parasite $O$. cumana was collected in 1990 from sunflower fields in Bulgaria. Seed of the host plant Helianthus annuus, cv. Iregi, from Hungary was used.

Observations on the underground stages of $O$. cumana in root chambers. The effect of $\mathrm{BTH}$ on the underground stages of $O$. cumana was evaluated in root chambers. The latter were used as described by Linke and Vogt (22). The chambers had backs and sides made of plastic while the front was closed with transparent Plexiglas. The dimensions of the root chambers were 20 by 6 by $2 \mathrm{~cm}$ (length, width, and depth). Nonpreconditioned Orobanche seed $(20 \mathrm{mg})$ was spread by hand on a wet strip $(26$ by $6 \mathrm{~cm})$ of nonbiodegradable microfiber glass filter paper (Whatman GF/A, Whatman International Ltd., Maidstone, England). The strips were placed in chambers filled with a mixture of sterilized clay and sand (2:1 volume proportion) and covered with the Plexiglas. The root chambers were covered with black plastic film and stored for 7 days at room temperature under dark conditions to precondition the $O$. cumana seed. Following this conditioning period, one sunflower seed was placed between the strip and the lid.

Sunflower seeds were presoaked for $36 \mathrm{~h}$ in BTH (CGA245704; Syngenta, Münchwilen, Switzerland), formulated as $50 \%$ active ingredient with a wettable powder (WP) carrier in water. Control seeds were treated with WP in water. To prevent light penetration, the chambers were wrapped in black plastic and placed at an angle so that sunflower roots had to grow near the surface of the Plexi-

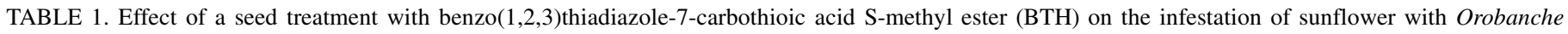
cumana and on dry matter in root chamber trials ${ }^{\mathrm{z}}$

\begin{tabular}{|c|c|c|c|c|c|}
\hline \multirow[b]{2}{*}{ Trial } & \multirow[b]{2}{*}{ BTH (ppm) } & \multicolumn{2}{|c|}{ Sunflower (g of dry matter) } & \multicolumn{2}{|c|}{ Orobanche cumana } \\
\hline & & Shoot & Root & Number & Dry matter (g) \\
\hline \multirow[t]{3}{*}{ I } & 0 & $0.12(0.03) \mathrm{a}$ & $0.08(0.06) \mathrm{a}$ & $33(13.23) \mathrm{a}$ & $0.02(0.006) \mathrm{a}$ \\
\hline & 40 & $0.10(0.03) \mathrm{a}$ & $0.02(0.01) \mathrm{a}$ & $0 \mathrm{~b}$ & $0 \mathrm{~b}$ \\
\hline & 60 & $0.03(0.03) \mathrm{a}$ & $0.01(0.01) \mathrm{a}$ & $0 \mathrm{~b}$ & $0 \mathrm{~b}$ \\
\hline \multirow[t]{3}{*}{ II } & 0 & $0.13(0.04) \mathrm{a}$ & $0.03(0.006) \mathrm{a}$ & $19.5(5.92) \mathrm{a}$ & $0.06(0.02) \mathrm{a}$ \\
\hline & 30 & $0.08(0.05) \mathrm{a}$ & $0.02(0.02) \mathrm{a}$ & $1.3(1.26) \mathrm{b}$ & $0.003(0.005) \mathrm{b}$ \\
\hline & 40 & $0.06(0.01) b$ & $0.02(0.01) \mathrm{a}$ & $0 \mathrm{c}$ & $0 \mathrm{c}$ \\
\hline
\end{tabular}

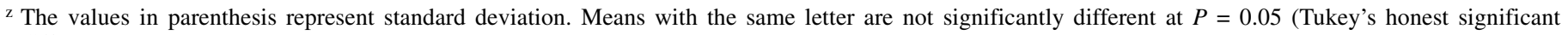
difference test).

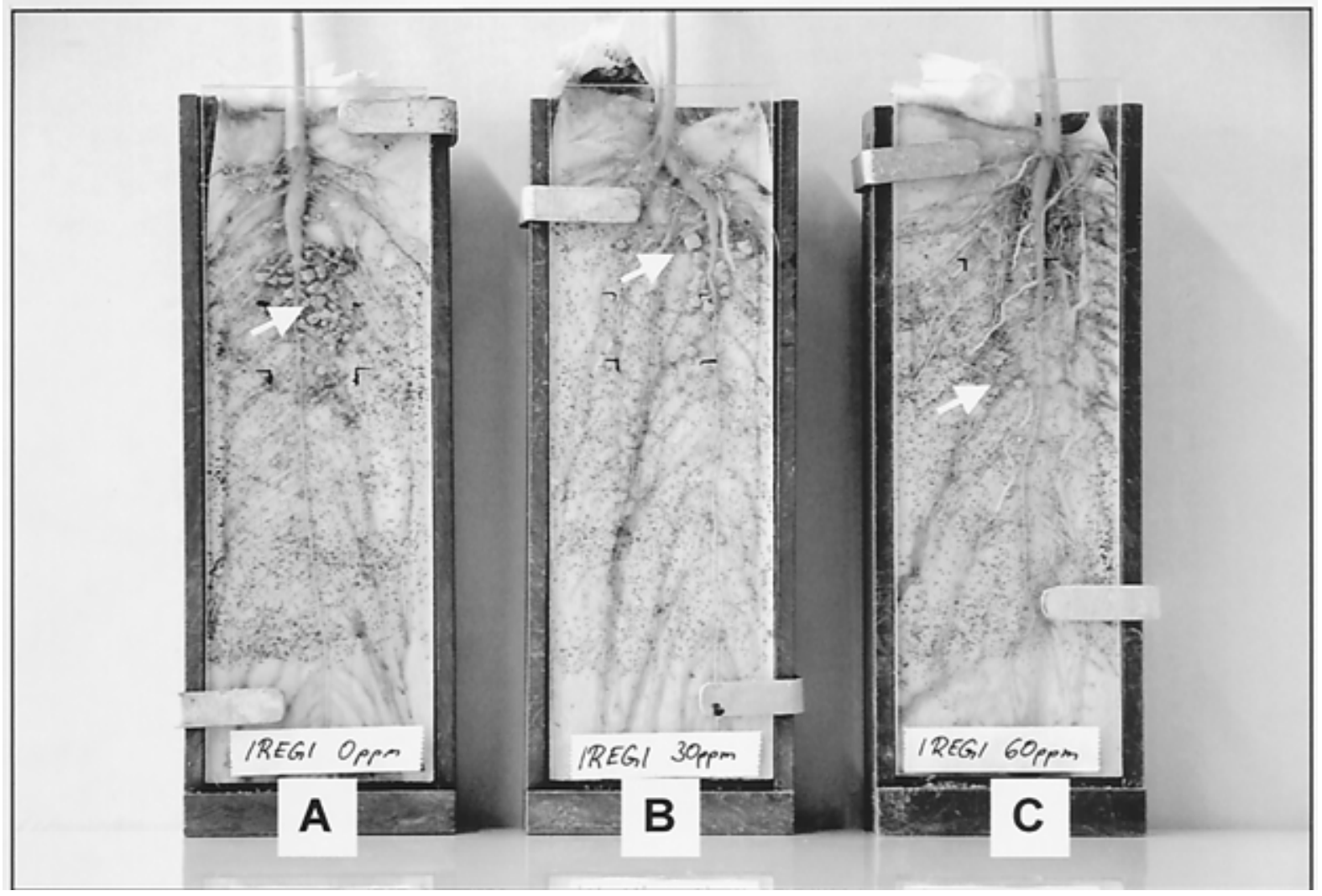

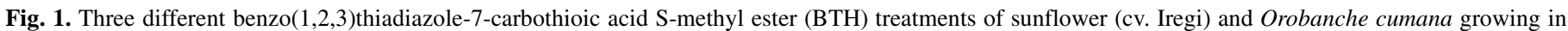

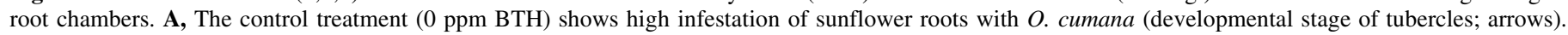

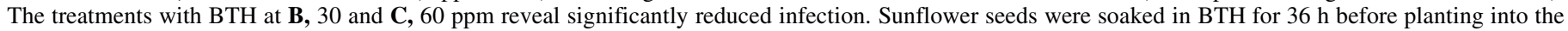
root chambers. 
glas plate. The experiments were placed in a glasshouse under controlled conditions where temperature ranged between $15^{\circ} \mathrm{C}$ (night) and $25^{\circ} \mathrm{C}$ (day). The day length was approximately $13 \mathrm{~h}$. Supplementary light was provided from HQLR-lamps (Radium, $1,000 \mathrm{~mW}$ ) when required. Plants were watered weekly with $10 \mathrm{ml}$ of tap water. Evaluation of infestation was done by means of a binocular microscope 50 days after sunflower planting by counting the number of Orobanche shoots attached to sunflower roots. Parasite and total host dry matter (shoot and roots) were assessed after drying at $80^{\circ} \mathrm{C}$ for $48 \mathrm{~h}$. The experiments were conducted in three replicates for the first set and in four replicates for the second set.

Pot trials to evaluate effect of induced resistance on $O$. cumana. Local field soil was mixed with sand $(1: 1, \mathrm{vol} / \mathrm{vol})$ to provide a loamy sand, $\mathrm{pH} 7$. Pots (12 by 12 by $18 \mathrm{~cm}$ ) were filled with $1 \mathrm{~kg}$ of soil. Approximately 14,000 O. cumana seed (50 mg) with a germinability of $76 \%$ were distributed onto the soil surface of each pot. Afterwards, the pots were filled with another $750 \mathrm{~g}$ of soil. Soil was watered with $100 \mathrm{ml}$ of tap water and the pots left for 7 days under greenhouse conditions in order to precondition $O$. cumana seed. Seed of sunflower were presoaked for $36 \mathrm{~h}$ in indicated amounts of BTH. One sunflower seed was planted per pot. Subsequently, the soil was allowed to dry before irrigation to a degree that sunflower showed reversible wilting symptoms. The experiments were conducted in the glasshouse with temperature and day length as mentioned before. Evaluation of the trials started 70 days after crop emergence. After washing off the soil from sunflower roots, parasite and total host dry matter (shoot and roots) were determined and the total number of $O$. cumana shoots per pot were counted. The experimental design was a randomized complete block with five repetitions. Experiments were repeated twice. All data were subjected to analyses of variance using the Statistica statistical package (1997). Significant differences in the mean values were determined by Tukey's honest significant difference (HSD) test at a significance level of 0.05 .

Viability assays on germinating seeds of $\boldsymbol{O}$. cumana and $\boldsymbol{H}$. annuus. To evaluate a possible toxic effect of BTH on germinating sunflower, seed were spread on a filter paper in petri dishes and BTH was added at 0 (control), 30, and $60 \mathrm{ppm}$.

Seed of $O$. cumana were spread on filter paper in petri dishes, preconditioned, and stimulated to germinate by the synthetic stimulant GR24 (supplied by B. Zwanenburg, Nijmegen, The Netherlands) as described by Goldwasser et al. (12). After induction of germination, BTH was added at 0 (control), 30, and $60 \mathrm{ppm}$. The dishes were stored under room temperature in the dark. The germination process and the survival rate were observed in 1-day intervals under a microscope for a period of 5 days.

Chemical analysis. For chemical analysis, 14-day-old sunflower plants were used. Fresh sunflower roots $(\approx 0.2 \mathrm{~g})$ were homogenized with $1 \mathrm{ml}$ of $\mathrm{MeOH}$ (Riedel-de Haen, Seelze, Germany) by means of an Ultra-Turrax (Heidolph, Schwarbach, Germany). After an incubation time of $15 \mathrm{~min}$, the extracts were filtrated by means of a syringe filter (PET, $\theta 15 \mathrm{~mm}$, pore size
$0.20 \mu \mathrm{m}$; Macherey-Nagel, Dueren, Germany), transferred into a fresh vial, and stored at $-20^{\circ} \mathrm{C}$ until use.

For high-performance liquid chromatography (HPLC), a system (Dionex, Idstein, Germany) combined with a diode array detector (DAD) and an analytical reversed phase column (Grom-Sil 120 ODS-5 ST; 250 by $4.6 \mathrm{~mm}$ i.d., $5 \mu \mathrm{m}$; Grom Analytik + HPLC $\mathrm{GmbH}$, Herrenberg, Germany) was used. The best separation of compounds was achieved by using $0.1 \%$ aqueous trifluoroacetic acid (Merck Eurolab GmbH, Darmstadt, Germany) in a gradient of 10 to $100 \%$ acetonitrile (Riedel-de Haen) over $65 \mathrm{~min}$ and under a constant flow of $1 \mathrm{ml} \mathrm{min}$. The compounds were detected simultaneously at 210, 225, 280, and $350 \mathrm{~nm}$. UV absorption spectra (from 200 to $400 \mathrm{~nm}$ ) of each compound peak were collected by the DAD. Scopoletin was identified and quantified by use of reference compound (Sigma-Aldrich, Deisenhofen, Germany). UV spectroscopy and HPLC-mass spectroscopy (LC-MS) were used for verification, as described elsewhere $(4,5)$. The lignin content was determined as described by Van Soest and Robertson (39).

For localization of $\mathrm{H}_{2} \mathrm{O}_{2}$ in root tissues, the vacuum infiltration method (DAB; Sigma-Aldrich, Deisenhofen, Germany) as described $(11,38)$ was used with 14 -day-old sunflower roots. As a control, roots were infiltrated in the same way with an additional $1 \mathrm{mM}$ ascorbate.

Gel electrophoresis and western blot analysis. Sodium dodecyl sulfate-polyacrylamide gel electrophoresis (SDS-PAGE) ( $15 \%$ polyacrylamide) and western blot analysis were performed on a commercial system according to the producer's recommendation (MiniProteanII; Biorad, München, Germany). Proteins were transferred onto nitrocellulose filters (Schleicher \& Schüll, Dassel, Germany) by electroblotting. Immunostaining of proteins was carried out using antiserum produced against a pathogen and salicylic acid inducible acid chitinase from sugar beet (class III chitinase; DANISCO, Copenhagen, Denmark) and a second antibody by means of the NBT/BCIP method. For calculating the size of the bands, prestained SDS-PAGE standards (BenchMark prestained protein ladder; Gibco, Eggenstein, Germany) were used.

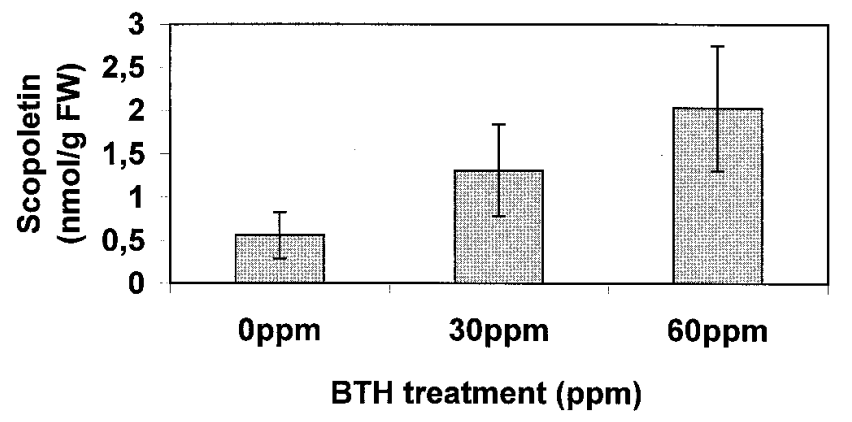

Fig. 2. Scopoletin concentration in sunflower (cv. Iregi) roots 14 days after benzo(1,2,3)thiadiazole-7-carbothioic acid S-methyl ester treatment (mean \pm $\mathrm{SD} ; n=6$ ) determined by high-performance liquid chromatography.

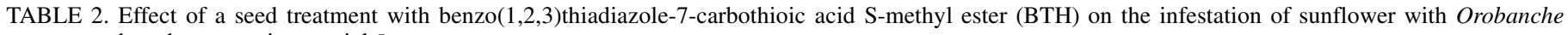
cumana and on dry matter in pot trials ${ }^{\mathrm{z}}$

\begin{tabular}{|c|c|c|c|c|c|}
\hline \multirow[b]{2}{*}{ Trial } & \multirow[b]{2}{*}{ BTH (ppm) } & \multicolumn{2}{|c|}{ Sunflower (g of dry matter) } & \multicolumn{2}{|c|}{ Orobanche cumana } \\
\hline & & Shoot & Root & Number & Dry matter $(\mathrm{g})$ \\
\hline \multirow[t]{3}{*}{ I } & 0 & $0.56(0.16) \mathrm{a}$ & $0.16(0.12) \mathrm{a}$ & $28.8(17.4) \mathrm{a}$ & $0.15(0.08) \mathrm{a}$ \\
\hline & 40 & $0.52(0.07) \mathrm{a}$ & $0.16(0.04) \mathrm{a}$ & $9.0(8.12) b$ & $0.07(0.07) \mathrm{a}$ \\
\hline & 60 & $0.55(0.08) \mathrm{a}$ & $0.11(0.05) \mathrm{a}$ & $4.6(2.97) b$ & $0.08(0.02) \mathrm{a}$ \\
\hline \multirow[t]{3}{*}{ II } & 0 & $0.38(0.10) \mathrm{a}$ & $0.09(0.04) \mathrm{a}$ & $9.5(5.34) \mathrm{a}$ & $0.03(0.02) \mathrm{a}$ \\
\hline & 40 & $0.30(0.16) \mathrm{a}$ & $0.12(0.06) \mathrm{a}$ & $1.0(1.22) \mathrm{b}$ & $0.02(0.02) \mathrm{a}$ \\
\hline & 60 & $0.31(0.13) \mathrm{a}$ & $0.05(0.05) \mathrm{a}$ & $0.4(0.55) \mathrm{b}$ & $0.03(0.05) \mathrm{a}$ \\
\hline
\end{tabular}

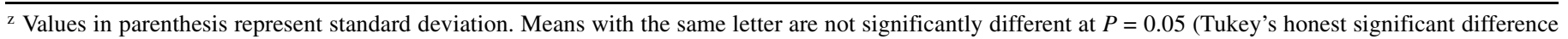
test). 


\section{RESULTS AND DISCUSSION}

Seeds of sunflower soaked for $36 \mathrm{~h}$ at $20^{\circ} \mathrm{C}$ in water were infested by an average of 33 and 19 O. cumana shoots in the first and second trial, respectively, conducted in root chambers. Soaking seed for $36 \mathrm{~h}$ in an aqueous solution of BTH reduced the infection of $H$. annuus by $O$. cumana. BTH applied at $30 \mathrm{ppm}$ reduced the rate of infection by $93 \%$. An application of BTH at 40 and $60 \mathrm{ppm}$ completely prevented infection of the sunflower plants (Table 1, Fig. 1).

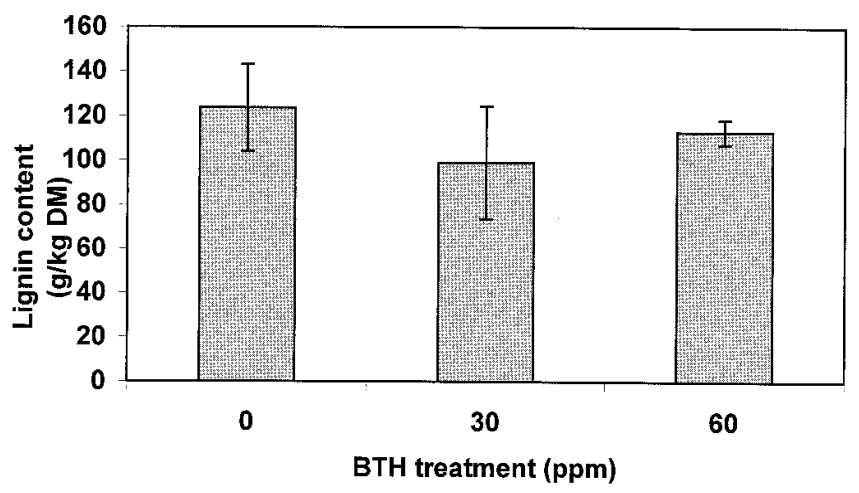

Fig. 3. Lignin content of sunflower (cv. Iregi) roots 14 days after benzo(1,2,3)thiadiazole-7-carbothioic acid S-methyl ester treatment (mean $\pm \mathrm{SD} ; n=4$ ).
BTH seed treatment had some influence on sunflower dry matter production (Table 1). Shoot as well as root dry matter decreased by 40 and $50 \%$ in the 30 -ppm BTH treatment in the first and second trial, respectively. Reduced biomass and seed production after BTH application had been described earlier for Triticum aestivum by Heil et al. (16). These authors interpreted growth depression as a consequence of allocation costs which might occur as a result of a metabolic competition between the production of biomass and energy for SAR-related defense reactions.

To test the effects of BTH on sunflower grown in soil, pot trials were conducted. Again, the number of successful attachments of $O$. cumana to sunflower roots decreased in a dose-dependent manner upon BTH seed soaking (Table 2). Total number of broomrape was reduced by 84 and $95 \%$ in the 60 -ppm BTH treatment in the first and second trial, respectively. The 40- and 30-ppm treatments reduced the number of successful infections by 69 and $89 \%$, respectively. In these pot experiments, sunflower shoot and root dry matter did not differ significantly under the different treatments (Table 2), indicating that growth reduction of sunflower plants in root chamber experiments is most possibly not due to allocation costs.

To exclude the possibility that reduced infestation is due to a phytotoxic effect of BTH on the germinating $O$. cumana seed, we performed germination tests in the presence of increasing concentrations of BTH. Here we revealed a germination rate of $88.2 \%$ $( \pm 1.6, n=7), 88.6 \%( \pm 5.3, n=7)$, and $87.0 \%( \pm 8.3, n=7)$ in the control, 30-ppm, and 60-ppm treatment, respectively. These re-

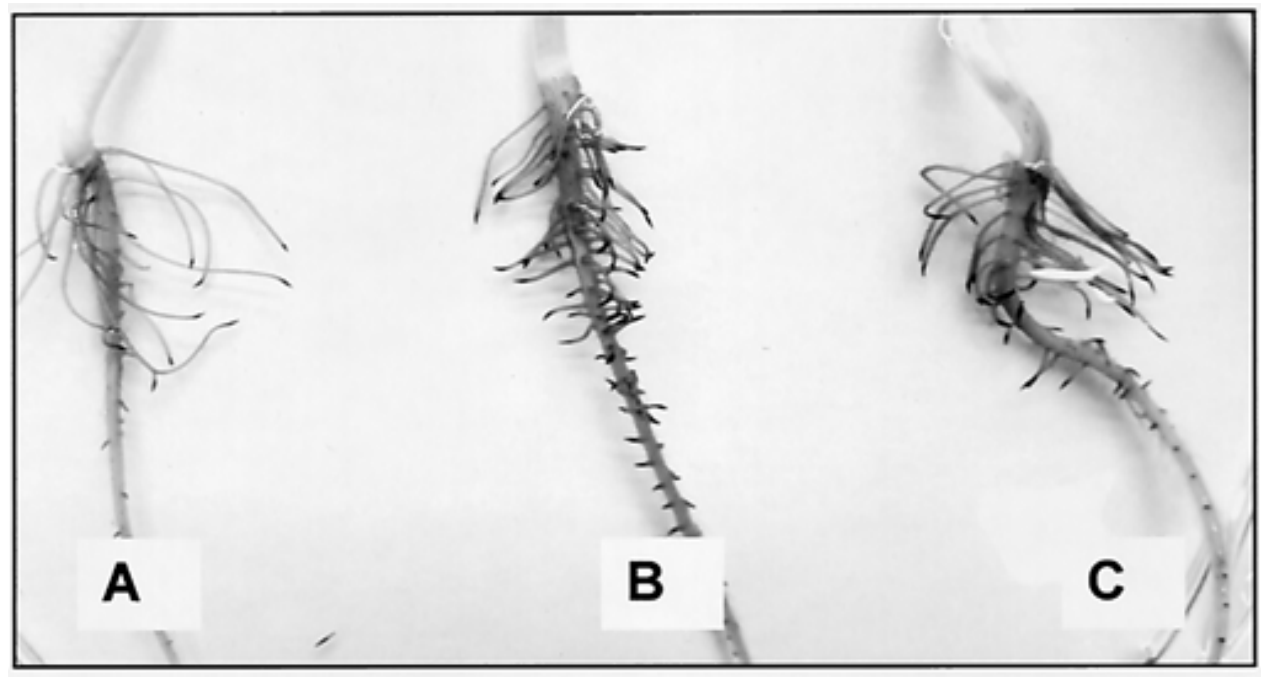

Fig. 4. Detection of $\mathrm{H}_{2} \mathrm{O}_{2}$ in sunflower roots (cv. Iregi) by means of vacuum infiltration with 3,3-diaminobenzidine tetrahydrochloride (DAB). The sunflowers were harvested and analysed 14 days after treatment with benzo(1,2,3)thiadiazole-7-carbothioic acid S-methyl ester (BTH). A, The control treatment (BTH at $0 \mathrm{ppm}$ ) shows slight concentrations of $\mathrm{H}_{2} \mathrm{O}_{2}$ in the sunflower roots. The treatments with $\mathrm{BTH}$ at $\mathbf{B}, 30$ and $\mathbf{C}, 60$ ppm were significantly more stained by DAB than the control.

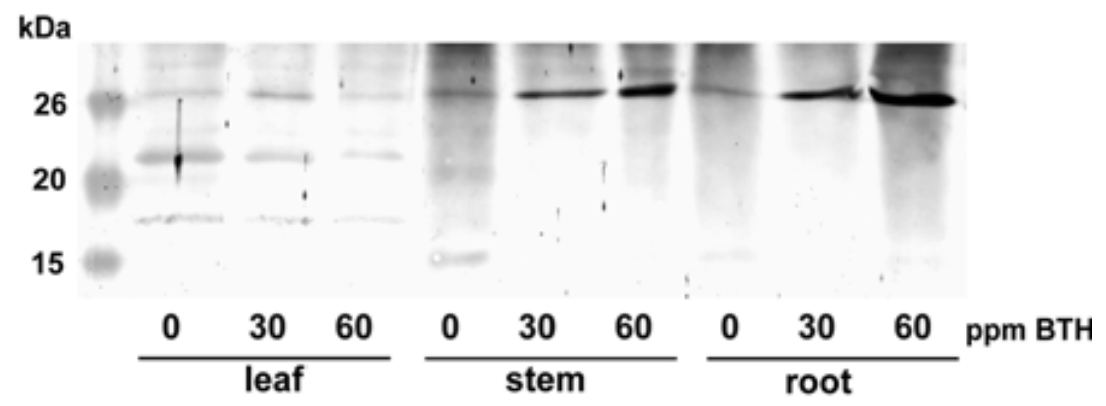

Fig. 5. Analysis of benzo(1,2,3)thiadiazole-7-carbothioic acid S-methyl ester (BTH)-induced acid chitinase (class III) accumulation in roots, stems, and leaves of sunflower plants. Sunflower seeds were drench treated with the indicated concentration of BTH and grown in pots for 14 days before harvesting. After separation by gel electrophoresis, proteins were immunostained using chitinase-specific antiserum. BTH-induced chitinase, showing up at $28 \mathrm{kDa}$, accumulated in a dose-dependent manner, especially in roots and stems. 
sults show no significant reduction of germination of BTH-treated Orobanche seed, demonstrating that there are no toxic effects of BTH on sunflower seed in the used concentration ranges.

The data strongly suggested that BTH does not act via a herbicidal activity but via induction in sunflower roots of the SAR pathway. To strengthen these findings, we analyzed BTH-induced plant defense responses with respect to accumulation of lowmolecular-weight defense compounds and PR protein accumulation. The analysis of sunflower root extracts showed significant qualitative and quantitative differences in compound composition after BTH treatment. Based on our ongoing investigations, these compounds are mainly secondary metabolites belonging to the phenylpropanoid group, like scopoletin. In particular, the concentration of scopoletin increased as a result of the BTH treatment (Fig. 2). Scopoletin is well known to function as a phytoalexin in sunflower (15) and was discussed as a factor of resistance to $O$. cumana by Wegmann et al. (43). The accumulation of phenylpropanoids in chemical-induced resistance corresponds with the investigations of Stadnik and Buchenauer (30), who found increased activities of phenylalanine ammonia-lyase (PAL), the key enzyme of the phenylpropanoid pathway, in BTH-treated wheat plants. Additionally, Katz et al. (20) described an increased activity of PAL and production of coumarin phytoalexins after BTH application in parsley (Petroselinum crispum) cells.

Some authors describe an increased lignification of cell walls around the penetration site as well as of the xylem vessels to function as a mechanical barrier in the sunflower roots toward infestation with $O$. cumana $(6,13)$. However, lignin is not preaccumulated in the roots after treatment with BTH (Fig. 3). This corresponds with the results of Stadnik and Buchenauer (29), who did not find an increase of lignin after BTH treatment in wheat.

Reactive oxygen intermediates (ROI), like hydrogen peroxide, play an important role in plant defense against pathogens (3). However, ROI have never been analyzed with regards to infections with parasitic weeds. The fact that Orobanche spp. produce high amounts of antioxidants (40) is a hint for the involvement of ROI in the interaction of this holoparasite with its hosts. An infestation of sunflower with $O$. cumana strongly enhances the accumulation of ROI at infection sites, but it is yet unclear as to whether the infection-related accumulation of oxygen intermediates is generated by the host, the parasitic plant, or both (unpublished data). To address the question of whether BTH treatment of sunflower seed induces an oxidative burst before an attack by $O$. cumana, we detected the $\mathrm{H}_{2} \mathrm{O}_{2}$ by means of the DAB colorization method and found an accumulation of this ROI in BTH-treated healthy sunflower roots (Fig. 4).

We addressed the question of whether BTH treatment induces chitinase, a PR protein widely used as SAR marker in dicotyledonous plants (31). Total proteins were extracted from roots, stems, and leaves of 14-day-old sunflower seedlings whose seed were soaked with BTH at 30 and $60 \mathrm{ppm}$ before planting. Chitinase accumulation was revealed by an antiserum generated against a class III chitinase from sugar beet. Chitinase accumulated in response to BTH in a dose-dependent manner in roots and stems and, to a minor extent, in leaves (Fig. 5).

The results presented here show for the first time induction of resistance of a crop plant against a parasitic flowering plant by means of a chemical. BTH was reported to stimulate resistance in mono- and dicotyledonous plants against a broad spectrum of viral, bacterial, and fungal parasites $(9,14,28)$. For sunflower, it was successfully used as foliar spray and soil drench to reduce the infestation with Plasmopara helianthi (36). The sequence of events by which BTH reduces successful infection by phytopathogenic fungi or attachment of $O$. cumana to sunflower roots is widely unknown. BTH, like other resistance inducers, activates various defense responses ranging from hypersensitive cell death (HR) of pathogen-attacked cells up to accumulation of ROI and the expression of a number of PR genes, which together might control microbial pathogens $(2,9,17,21)$. In incompatible Orobanche spp.-host plant interactions, evidence has been furnished for an involvement of PR proteins, including a PR1 homologue (19) and 3-hydroxy-3-methylglutaryl CoA reductase (44). On the basis of histopathological data presented by Dörr et al. (6) and others (44) along with our own unpublished observations that show necrotization and browning at penetration sites associated with resistant interaction phenotypes, one can speculate about the involvement of peroxidases and $\mathrm{H}_{2} \mathrm{O}_{2}$ as resistance factors. These factors are known for their role in cross-linking reactions of soluble cell wall components such as proteins and phenylpropanoids, resulting in cell wall toughening and, consequently, in penetration resistance.

Taking interaction of powdery mildew fungus (Blumeria graminis) with cereals such as barley and wheat as a model to demonstrate chemical induced resistance to pathogens $(2,14,21)$, the mechanistic analogy between haustorium formation in this system and in sunflower plants attacked by $O$. cumana is evident. In barley, penetration resistance to infection by powdery mildew fungus highly correlates with the formation of cell wall appositions in which low-molecular-weight compounds (41) as well as peroxidases, concomitantly with their substrate $\mathrm{H}_{2} \mathrm{O}_{2}(18,35)$, strongly accumulate. In contrast, successful infection (i.e., establishment of an active interface between haustorium and host plant) is linked to suppression of $\mathrm{H}_{2} \mathrm{O}_{2}$ generation, suggesting that the antioxidative status of attacked host cells is decisive for the outcome of the interaction (17). It is tempting to speculate that this biochemical sequence applies equally to sunflower resistance against O. cumana.

\section{LITERATURE CITED}

1. Antonova, T. S., and ter Borg, S. J. 1996. The role of peroxidase in the resistance of sunflower against Orobanche cumana in Russia. Weed Res. 36:113-121.

2. Beßer, K., Jarosch, B., Langen, G., and Kogel, K.-H. 2000. Expression analysis of genes induced in barley after chemical activation reveals distinct disease resistance pathways. Mol. Plant Pathol. 1:277-286.

3. Bradley, D. J., Kjellbom, P., and Lamb, C. J. 1992. Elicitor- and woundinduced oxidative cross-linking of a proline-rich plant cell wall protein: a novel rapid defense response. Cell 70:21-30.

4. Buschmann, H., Reilly, K., Rodriguez, M. X., Tohme, J., and Beeching, J. R. 2000. Hydrogen peroxide and flavan-3-ols involved in post-harvest deterioration of tuberous roots of cassava (Manihot esculenta Crantz). J. Agric. Food Chem. 48:5522-5529.

5. Buschmann, H., Rodriguez, M. X., Tohme, J., and Beeching, J. R. 2000. Hydroxycoumarins involved in post-harvest physiological deterioration of tuberous roots of cassava (Manihot esculenta Crantz). Ann. Bot. 86:1153-1160.

6. Dörr, I., Staack, A., and Kollmann, R. 1994. Resistance of Helianthus to Orobanche-histological and cytological studies. Pages 276-289 in: Proc. 3rd Int. Workshop Orobanche and Related Striga Res. A. H. Pieterse, J. A. C. Verkleij, and S. J. ter Borg, eds. Royal Tropical Institute, Amsterdam, The Netherlands.

7. Encheva, V., and Shindrova, P. 1994. Broomrape (Orobanche cumana Wallr.)-A hindrance to sunflower production in Bulgaria. Pages 619622 in: Proc. 3rd Int. Workshop Orobanche and Related Striga Res. A. H. Pieterse, J. A. C. Verkleij, and S. J. ter Borg, eds. Royal Tropical Institute, Amsterdam, The Netherlands.

8. FAO 1999. FAO Production Yearbook 1998, Vol. 52. FAO, Rome, Italy.

9. Friedrich, L., Lawton, K., Ruess, W., Masner, P., Specker, N., Gut Rella, M., Meier, B., Dincher, S., Staub, T., Ukness, S., Métraux J.-P., Kessmann, H., and Ryals, J. 1996. A benzothiadiazole derivative induces systemic acquired resistance in tobacco. Plant J. 10:61-70.

10. Garcia Torres, L., Castejan-Munoz, M., and Lopez-Granados, F. 1994. The Problem of Orobanche and its management in Spain. Pages 623-627 in: Proc. 3rd Int. Workshop Orobanche and Related Striga Res. A. H. Pieterse, J. A. C. Verkleij, and S. J. ter Borg, eds. Royal Tropical Institute, Amsterdam, The Netherlands.

11. Gay, C., Collins, J., and Gebicki, J. M. 1999. Hydoperoxide assay with ferric-xylenol orange complex. Anal. Biochem. 273:149-155.

12. Goldwasser, Y., Hershenhorn, J., Plakhine, D., Kleifeld, Y., and Rubin, B. 1999. Biochemical factors involved in vetch resistance to Orobanche aegyptiaca. Physiol. Mol. Plant Pathol. 54:87-96.

13. Goldwasser, Y., Hershenhorn, J., Rubin, B., Zamski, E., Plakhine, D., 
and Kleifeld, Y. 1998. Factors involved in resistance of Vicia atropurpurea to Orobanche aegyptiaca. In: Curr. Prob. Orobanche Res. Proc. 4th Int. Workshop Orobanche. K. Wegmann, L. Musselman, and D. Joel, eds. Albena, Bulgaria.

14. Görlach, J., Volrath, S., Oostendorp, M., Kogel, K.-H., Beckhove, U., Staub, T., Ward, E., Kessmann, H., and Ryals, J. 1996. Benzothiadiazole, a novel class of inducers of systemic acquired resistance, activates induced systemic resistance in wheat. Plant Cell 8:629-643.

15. Gutierrez, M. C., Parry, A., Tena, M., Jorrin, J., and Edwards, R. 1995. Abiotic elicitation of coumarin phytoalexins in sunflower. Phytochemistry 38:1185-1191.

16. Heil, M., Hilpert, A., Kaiser, W., and Linsenmair, K. E. 2000. Reduced growth and seed set following chemical induction of pathogen defense: Does systemic acquired resistance (SAR) incur allocation costs? J. Ecol. 88:645-654.

17. Hückelhoven, R., Fodor, J., Preis, C., and Kogel, K.-H. 1999. Hypersensitive cell death and papilla formation in barley attacked by the powdery mildew fungus are associated with hydrogen peroxide but not with salicylic acid accumulation. Plant Physiol. 119:1251-1260.

18. Hückelhoven, R., Fodor, J., Trujillo, M., and Kogel, K.-H. 2000. Barley Mla- and Rar-mutants compromised in the hypersensitive cell death response against Blumeria graminis f. sp. hordei are modified in their ability to accumulate reactive oxygen intermediates at sites of fungal invasion. Planta 212:16-24.

19. Joel, D. M., and Losner-Goshen, D. 1994. Early host-parasite interaction: models and observations of host root penetration by haustorium of Orobanche. Pages 237-247 in: Proc. 3rd Int. Workshop Orobanche and Related Striga Res. A. H. Pieterse, J. A. C. Verkleij, and S. J. ter Borg, eds. Royal Tropical Institute, Amsterdam, The Netherlands.

20. Katz, V. A., Thulke, O. U., and Conrath, U. 1998. A benzothiadiazole primes parsley cells for augmented elicitation of defense responses. Plant Physiol. 117:1333-1339.

21. Kogel, K.-H., Beckhove, U., Dreschers, J., Münch, S., and Rommé, Y. 1994. Acquired resistance in barley: Analysis of the interaction with powdery mildew reveals the mechanism induced by 2,6-dichloroisonicotinic acid as a phenocopy of a genetically based mechanism governing race-specific resistance. Plant Physiol. 106:1269-1277.

22. Linke, H.-H., and Vogt, W. 1987. A method and its application for observing germination and early development of Striga (Scrophulariaceae) and Orobanche (Orobanchaceae). Pages 501-509 in: Proc. 4th Int. Symp. Parasitic Flowering Plants. H. C. Weber and W. Forstreuter, eds. Phillips University, Marburg, Germany.

23. Liu, L., and Li, X. 1988. The geographical distribution of sunflower disease in China. Plant Pathol. 37:470-474.

24. Lucas, J. A. 1999. Plant immunization: From myth to SAR. Pestic. Sci. 55:193-196.

25. Mijatovic, K., and Stojanovic, D. 1973. Distribution of Orobanche spp. on the agricultural crops in Yugoslavia. Pages 28-34 in: Proc. Int. Symp. Parasitic Weeds. European Weed Research Council, Malta.

26. Parker, C. 1994. The present state of the Orobanche problem 1994. Pages 17-26 in: Proc. 3rd Int. Workshop Orobanche and Related Striga Res. A. H. Pieterse, J. A. C. Verkleij, and S. J. ter Borg, eds. Royal Tropical Institute, Amsterdam, The Netherlands.

27. Sauerborn, J. 1991. Parasitic flowering plants in agricultural ecosystems of West Asia. Flora Veg. Mundi 9:83-93.

28. Siegrist, J., Mühlenbeck, S., and Buchenauer, H. 1998. Cultured parsley cells, a model system for the rapid testing of abiotic and natural substances as inducers of systemic acquired resistance. Physiol. Mol. Plant Pathol. 53:223-238.

29. Stadnik, M. J., and Buchenauer, H. 1999. Accumulation of autofluoro- genic compounds at the penetration site of Blumeria graminis f. sp. tritici is associated with both benzothiadiazole-induced and quantitative resistance of wheat. J. Phytopathol. 147:615-622.

30. Stadnik, M. J., and Buchenauer, H. 2000. Inhibition of phenylalanine ammonia-lyase suppresses the resistance induced by benzothiadiazole in wheat to Blumeria graminis f. sp. tritici. Physiol. Mol. Plant Pathol. 57:25-34.

31. Sticher, L., Mauch-Mani, B., and Métraux, J. P. 1997. Systemic acquired resistance. Annu. Rev. Phytopathol. 35:235-270.

32. Szöko, G. 1973. Investigations on the effect of $O$. cumana on sunflower. Acta Phytopathol. Acad. Sci. Hung. 8:375-380.

33. Thomas, H., Heller, A., Sauerborn, J., and Müller-Stöver, D. 1999. Fusarium oxysporum f. sp. orthoceras, a potential mycoherbicide, parasitizes seeds of Orobanche cumana (sunflower broomrape): A cytological study. Ann. Bot. 83:453-458.

34. Thomas, H., Sauerborn, J., Mueller-Stoever, D., Ziegler, A., Bedi, J., and Kroschel, J. 1998. Potential of Fusarium oxysporum f. sp. orthoceras as a biological control agent for Orobanche cumana in sunflower. Bio. Control 13:41-48.

35. Thordal-Christensen, H., Zhang, Z., Wei, Y., and Collinge, D. B. 1997. Subcellular localization of $\mathrm{H}_{2} \mathrm{O}_{2}$ in Plants. $\mathrm{H}_{2} \mathrm{O}_{2}$ accumulation in papillae and hypersensitive response during the barley-powdery mildew interaction. Plant J. 11:1187-1194.

36. Tosi, L., Luigetti, R., and Zazzeroni, A. 1999. Benzothiadiazole induces resistance to Plasmopara helianthi in sunflower plants. J. Phytopathol. 147:365-370.

37. Uknes, S. J., Mauch-Mani, B., Moyer, M., Potter, S., Williams, S., Dincher, S., Chandler, D., Slusarenko, A., Ward, E., and Ryals, J. 1992. Acquired resistance in Arabidopsis. Plant Cell 4:645-656.

38. Vallélian-Bindschedler, L., Schweizer, P., Mösinger, E., and Métraux, J.P. 1998. Heat-induced resistance in barley to powdery mildew (Blumeria graminis f. sp. hordei) is associated with a burst of active oxygen species. Physiol. Mol. Plant Pathol. 52:185-199.

39. Van Soest, P. J., and Robertson, J. B. 1985. Analysis of Forages and Fibrous Foods. Laboratory Manual for Animal Science. Cornell University, Ithaca, NY.

40. Viron, C., Lhermite, S., Andre, P., and Lafosse, M. 1998. Isolation of phenylpropanoid glycosides from Orobanche rapum by high speed countercurrent chromatography. Phytochem. Anal. 9:39-43.

41. Von Röpenack, E., Parr, A., and Schulze-Lefert, P. 1998. Structural analyses and dynamics of soluble and cell wall-bound phenolics in a broad spectrum resistance to the powdery mildew fungus in barley. J. Biol. Chem. 273:9013-9022.

42. Ward, E. R., Uknes, S. J., William, S. C., Dincher, S. S., Wiederhold, D. L., Alexander, D. C., Ahl-Goy, P., Métraux, J. P., and Ryals, J. 1991. Coordinate gene activation in response to agents that induce systemic acquired resistance. Plant Cell 3:1085-1094.

43. Wegmann, K., von Elert, E., Harlof, H.-J., and Stadler, M. 1991. Tolerance and resistance to Orobanche. Pages 318-321 in: Progr. Orobanche Res. Proc. Int. Workshop Orobanche Res. K. Wegmann and L. Musselman, eds. Tübingen, Germany.

44. Westwood, J. H., Yu, X., Foy, C. L., and Cramer, C. L. 1998. Expression of a defense-related 3-hydroxy-3-methylglutaryl CoA reductase gene in response to parasitization by Orobanche spp. Mol. Plant-Microbe Interact. 11:530-536.

45. Zaitoun, F. M. F., and ter Borg, S. J. 1994. Resistance against Orobanche crenata in Egyptian and Spanish faba beans. Pages 619-622 in: Proc. 3rd Int. Workshop Orobanche and Related Striga Res. A. H. Pieterse, J. A. C. Verkleij, and S. J. ter Borg, eds. Royal Tropical Institute, Amsterdam, The Netherlands. 